\title{
Characteristics of Speech Mechanism and Motor Abilities in Adults Who Stutter
}

\author{
Seyeon Jeong', Moonja Shin ${ }^{2}$ \\ ${ }^{1}$ Green Field, Department of Speech-Language Pathology, Graduate School of Chosun University, Gwangju, Korea \\ ${ }^{2}$ Department of Speech-Language Pathology of Chosun University, Gwangju, Korea
}

말더듬성인의 조음기관 구조 및 기능 특성

정 세 연 $\cdot$ 신 문 자 ${ }^{2}$

푸른들, 조선대학교 언어치료학과 대학원 ${ }^{1}$ 조선대학교 언어치료학과 ${ }^{2}$

Purpose: The importance of oral motor abilities in stuttering occurrences has been continuously debated and discussed. The purpose of this study was to determine whether there would be a difference in speech mechanism and motor abilities between adults who stutter (AWS) and adults who do not stutter (AWNS). Methods: A total of 34 subjects participated in this study: 17 AWS (14 males and 3 females; mean age, 32 yrs 9 months) over 20 years old and 17 AWNS matched chronological age and sex with the former group. Each of the participants was directly examined on the basis of 13 items of structure and 17 items of function of speech mechanism. Results: There was no significant difference in speech structure and function between the two groups. Conclusion: In speech mechanism and motor ability assessment, a significant difference was not found in any areas, including structure and function, between AWS and AWNS. However, there may be individual variations, and for this reason, if there are any areas that might be problematic, even in the most fundamental areas, this should be taken into careful consideration. More considerable examination should be taken than direct observation of oral structure and function when it is doubtful.

Key Words: Speech mechanism, Oral motor abilities, Stutter.

Received: June 10, 2016 / Revised: June 28, 2016 / Accepted: July 5, 2016

Correspondence: Shin Moonja, Department of Speech-Language Pathology of Chosun University, 309 Pilmun-daero, Dong-gu, Gwangju 61452, Korea Tel: +82-62-230-6187 / Fax: +82-62-230-6271 / E-mail: moonjashin@chosun.ac.kr

\section{INTRODUCTION}

최근 연구들은 말더듬의 원인을 단일하게 규정하지 않는다 (Riley \& Riley, 2000; Smith, 1999; Starkweather \& Gottwald, 1990). 연구자들은 말더듬이 발생하고 진전하는 데에 다양한 요인이 작용할 수 있다고 본다. 말더듬의 원인을 한 가지로 규 정하지 않는 것이 바로 다요인적 관점이다. 다요인적 관점에서 주요하게 살피는 요인 중 하나로 말더듬는 사람의 구강운동능 력(oral motor abilities)을 꼽을 수 있다. 다요인적 모델은 말더 듬의 시작과 지속에 있어 개인의 생리-기질적인 소인과 말-언 어적인 요인, 심리적인 요인 그리고 환경적인 요인이 다양하게 상호작용한다고 본다(Smith, 1999; Starkweather \& Gottwald, 1990). 그러므로 연구자는 말더듬이 발생하는 전체적인 역동적 상호작용을 살피고 한편으로는 각각의 개별적인 요소 하나하
나를 집중하여 조사할 필요가 있다.

정상적인 말 산출에 있어서, 구강운동능력은 독립적으로 기 능하지 않으며 말하는 사람의 말-언어적인 요인 및 심리적인 요인 등과 적절히 상호작용한다. 특히, 말더듬는 사람들은 같은 단어라도 어느 때는 유창하게 말하지만 어떤 경우에는 부적절 하게 비유창하게 말하게 된다.

여기서 구강운동능력은 흔히 조음기관 구조 및 기능이라는 용어와 혼용해 쓰이기도 하고 조음기관 구조 및 기능보다는 좀 더 포괄적인 의미로 사용되기도 한다. 말더듬의 원인을 구강운 동능력에서 살펴보고자 하는 시도가 여러 연구를 통해 이뤄져 왔다. 특히, 구강운동능력이 말더듬에 미치는 영향은 다른 말 더듬 요인에 비해 적지 않은 것으로 알려져 있다(Alpermann \& Zückner, 2008; Cook et al., 2011; Hutchinson \& Watkin, 1976; Riley \& Riley, 1979; Riley \& Riley, 1986; Riley \& Riley, 
2000; Smith, 1999; Van Lieshout et al., 1996). 그 중에서도, Cook et al.(2011)은 말더듬는 사람들 중에서 조음기관 구조 및 기능이 더 좋은 사람에게서 더 나은 치료효과가 나타났다고 보 고하였으며, Riley \& Riley(1986)는 말더듬아동을 대상으로 구 어적 구강운동 프로그램을 실시하는 것만으로 전체 $62 \%$ 의 아 동에게서 말더듬이 개선되었다고 보고하였다. 그런 이유로 말 더듬 평가 및 치료에 있어 구강운동 영역을 반드시 포함해야 한다고 강조하기도 하였다. 여러 연구자가 말더듬는 사람의 구 강운동능력 그리고 그에 따른 중재 효과에 대하여 지적하였다. 이러한 중요성에도 불구하고 국내에서는 말더듬는 사람의 구 강운동능력에 주목한 연구가 거의 없는 실정이다. 다요인적 관 점에서 구강운동능력은 주요하게 다뤄지기 때문에, 명확한 말 더듬 치료 기법의 개발을 위해 말더듬는 사람의 구강운동능력 을 연구하는 것은 중요하다. 그런 이유로 본 연구자는 구강운 동능력과 말더듬의 상관성을 검증해보고자 하였다.

그런데 한 가지 주의할 것은 언어처리 과정과 운동 과정은 매 우 밀접하게 연결되어 있다는 것이다. 그래서 미흡한 언어능력 은 말운동 과정에 직접 영향을 주어 말더듬의 발생 요인이 될 수 있다(Anderson \& Conture, 2000; Dworzynski et al., 2003). 이처럼 말 산출에 있어 언어와 운동과정은 하나의 연속선상에 있다. 즉 언어처리 과정에 오류가 있었다면, 그 오류는 발화 산 출에까지 전이되기 쉽다. 그런 이유로 운동과 관련된 요소가 말더듬에 영향을 주는 것인지 명확히 확인하기 위해서는 말더 듬이 언어적 과정에서 나타난 문제로 비롯된 결과가 아니라는 것을 구별할 필요가 있다(Howell, 2010). 즉 대상자의 언어처리 과정상 발생한 문제를 배제한 상태에서 최대한 직접적인 방식 으로 구강운동능력 혹은 조음기관 구조 및 기능을 평가할 수 있어야 한다는 것이다.

말더듬 발생에 있어서 구강운동능력(oral motor abilities)의 중요성과 필요성이 지속해서 언급되어 왔음에도 불구하고(Caruso et al., 1988), 대부분의 연구들은 언어능력이 포함된 형태 로 구강운동능력을 조사해왔다. 그렇기 때문에 본 연구자는 언 어능력이 포함되지 않은 형태로, 말 산출에 관여하는 조음기관 구조 및 기능을 평가할 수 있는 조음기관 구조·기능 선별검사 (Speech Mechanism Screening Test, SMST) (Shin et al., 2010) 를 이용해 말더듬성인과 일반성인 간 조음기관 구조 및 기능에 서 유의한 차이가 나타나는지 다양한 영역(얼굴, 입술, 혀, 턱과 치아, 경구개 및 연구개, 인두, 호흡)에서 그 차이를 규명해 보고 자 하였다.

\section{MATERIALS AND METHODS}

\section{연구 대상}

대상자는 조선대학교 생명윤리 심의위원회(Institutional Review Board, 승인번호: K-2013-11830259)의 승인 하에 모집 및 선정되었다. 연구에 참여한 성인은 총 34명으로 말더듬성인 17 명(남성 14명, 여성 3명)과 이에 생활연령, 성비, 학력 등을 일치 시킨 일반성인 17 명(남성 14 명, 여성 3명)이었다. 실험군 모집에 있어 성비를 따로 고려한 것은 아니며, 치료실에 내원한 사람들 중 실험군 선정기준에 부합하기만 하면, 모두 검사를 실시하였 다. 이는 말더듬 출현율(prevalence) 남녀 성비(약 $4: 1$ )에 부합 하였다(Craig et al., 2002). 말더듬성인의 평균연령은 약 32세 9 개월(연령범위: 19세 11 개월 57세 9개월)이었으며, 일반성인의 평균연령은 약 32세 3개월(연령범위: 20세 3개월 57세 1개월) 이었다.

\section{연구 대상 선정 기준}

\section{말더듬성인}

말더듬성인의 선정기준은 다음과 같았다. 1) 스스로 말을 더 듬는다고 보고하고 그로 인한 문제의식이 있어야 한다. 2) 파라 다이스-유창성 검사-II (Paradise-Fluency Assessment-II, P-FA-II) (Sim et al., 2010)에서 '약함' 이상의 말더듬으로 진 단되어야 한다. 3) 신경학적 말더듬 또는 심인성 말더듬이 아닌 발달성 말더듬 문제를 가진 대상자여야 한다. 4) 사전 인터뷰를 하는 동안 청각, 시각 및 신경학적 문제를 보이지 않아야 한다. 5) 말더듬을 제외한 언어장애 및 정신 및 인지장애에 대한 이력 이 없어야 한다. 6) 조음기관 구조 및 기능에 대한 특별한 지식 을 보유하고 있지 않아야 한다. 7) 근육 이상과 관련한 운동신 경질환으로 진단받은 이력이 없어야 한다. 8) 고등학교 졸업 이 상의 학력을 가진 사람이어야 한다. 실험군의 P-FA-II 검사는 모두 제1저자에 의하여 행하여졌으며 이들은 모두 위 조건을 모두 충족하였다.

\section{일반성인}

실험군과 연령 및 성비 그리고 학력을 일치시킨 일반성인의 선정기준은 다음과 같았다. 1) 말-언어장애 관련 이력이 없어야 한다. 2) 사전 인터뷰를 하는 동안 청각, 시각 및 신경학적 문제 를 보이지 않아야 한다. 3) 정신 및 인지 장애 관련 이력이 없어 야 한다. 4) 조음기관 구조 및 기능에 대한 특별한 지식을 보유 하고 있지 않아야 한다. 5) 고등학교 졸업 이상의 학력을 가진 사람이어야 한다. 이들 대조군은 위 조건을 모두 충족하였다. 


\section{연구 절차}

실험을 시작하기 전 본 연구자는 턱과 치아 영역에서 부정교 합 등의 정상성 판별을 위해 20년 이상 경력의 치과 전문의(보 철과 전문의)에게 훈련을 받았다. 치과에 내원한 환자를 대상 으로 채득한 인상을 훈련에 사용하였다. 본 검사는 방해를 받 지 않는 밀폐된 조용한 공간에서 대상자와 $1: 1$ 로 마주한 상태 에서 실시하였다. 검사 전 대상자들에게 연구동의서를 제공하 고 대상자가 알아듣기 쉽게 검사 방법을 약 10 분간 설명하였 다. 말더듬성인의 경우 본 검사 전 연구동의서를 받고 사례면담 지를 작성한 후 말더듬 중증도 검사(파라다이스-유창성검 사-II, P-FA-II) (Sim et al., 2010)를 하였다. 그리고 마지막으 로 조음기관 구조·기능 선별검사(SMST) (Shin et al., 2010)의 제1부인 '조음기관 구조 및 기능' 부분을 실시하였다(Appendix 1). 일반성인의 경우 연구동의서를 받고 사례면담지를 작성한 후 SMST를 실시하였다. SMST 실시 과정에서 조음기관 구조 및 기능 제한 정도를 즉시 기록하였다.

SMST는 세 가지 범주로 구성되어 있는데, 그 중 '발성, 음성 및 조음선별' 범주와 ‘조음교대운동' 범주를 제외한 ‘조음기관 구조와 기능' 범주만을 검사하였다. 그 이유는 '조음기관의 구 조와 기능' 범주 외 두 가지 범주 모두 구어적인 요소가 검사에 포함돼 있으며 또한 ‘발성, 음성 및 조음선별’ 범주에 포함된 ‘음 성검사' 등과 같은 영역은 구강운동능력 혹은 조음기관 구조 및 기능과는 별도의 검사 영역으로 볼 수 있기 때문이었다. 즉 ‘발성, 음성 및 조음선별’ 검사는 구강운동능력을 평가하는 검 사도구들에서는 흔히 실시하지 않는 영역이었으며(Dworkin \& Culatta, 1996; Louis \& Ruscello, 2000; Marshalla, 2008; Robbins \& Klee, 1987; Shipley \& McAfee, 2008), '조음교대 운동'은 본 연구에서 확인하고자 하는 직접적인 방식의 조음기 관 구조 및 기능 검사라는 특정한 범위를 벗어나기 때문에, 다 른 영역의 영향을 최소한으로 하고자 해당 범주만을 실험하였 다. 본 연구에서 보고자 하는 것은 말더듬성인의 조음기관 구 조 및 기능에 관한 것이지 말더듬성인의 말 산출 체계 전반을 모두 평가하고자 한 것은 아니었기 때문이다.

직접적인 방식의 조음기관 구조 및 기능 검사에 초점을 두기 위해 그 외의 검사 영역은 제외하였다. SMST 실시에 사용된 도구는 1회용 장갑과 1 회용 설압자, 진료용 조명등 $(\mathrm{CK}-907$, SPIRIT; Chinkou Medical Instrument, Taiwan)이었다. 또한, 말더듬성인의 경우 말더듬 중증도 평가를 위해 말더듬 검사 과 정을 비디오녹화(F320L; LG, Pyeongtaek, Korea)하였다. 조 음기관 구조 및 기능의 세부 영역은 얼굴, 입술, 혀, 턱과 치아, 경구개 및 연구개, 인두, 호흡 영역이며, 구조를 평가하는 13항 목과 기능을 평가하는 17항목으로 구성되어 있다. 그리고 모든 항목은 시청각적인 관찰로 평가되었다. 조음기관의 구조를 평가
하는 13 항목과 조음기관의 기능을 평가하는 17 항목의 점수를 구조와 기능으로 분리하여 각 영역별 점수를 산출하였다. 검사 에서 각각의 항목은 0 2점 척도로 되어 있으며, 0점은 '심각한 비정상', 1점은 ‘약간 비정상', 2점은 ‘정상'으로 처리하였다. 구조 총점은 26점이며, 기능 총점은 34점이다. 영역별 점수 혹은 총 점이 높을수록 정상적인 조음기관 구조 및 기능에 가까운 것으 로 볼 수 있다.

\section{신뢰도}

\section{검사자내 신뢰도}

검사자내 신뢰도 평가를 위해 전체 대상자의 $20 \%$ 에 해당하 는 인원을 2 3주 후 직접 다시 만나 재검사를 실시하였다. 선별 된 대상자의 자료에 대한 검사자내 일치율은 조음기관 구조 및 기능 전(全) 영역에서 $100 \%$ 로 나타났다.

\section{검사자간 신뢰도}

본 연구에서 평가한 영역들 중에는 턱과 치아 영역 등 언어재 활사보다는 치과 전문의가 더욱 정확히 볼 수 있는 영역이 존재 했다. 그래서 전체 대상자의 $20 \%$ 에 해당하는 인원이 언어재활 사가 아닌 치과전문의에게 직접 검사되었다. 선별된 대상자의 검사 결과에 대하여 본 연구자와 치과전문의 간에 조음기관 구 조 및 기능 측정에 대하여 일치하는 정도를 평가하였다.

영역별 일치율을 보면, 혀 영역 구조와 경구개 및 연구개 영 역 구조의 일치율은 $92.9 \%$, 턱과 치아 영역 구조 $61.9 \%$ 이며, 경 구개 및 연구개 영역 기능 $92.9 \%$, 호흡 영역 기능 $92.9 \%$ 나머 지 영역은 모두 $100 \%$ 였다. 결과적으로 조음기관 구조는 $89.0 \%$, 조음기관 기능은 $97.9 \%$ 의 일치율을 나타냈다.

\section{통계분석}

첫째, 종속변수의 정규성 가정 충족 여부를 판단하기 위해 Shapiro-Wilk의 정규성 검정을 실시하였다. 조음기관 구조와 기능을 측정하는 항목들 중, 두 개 이상의 항목으로 구성된 영 역에 대해서 정규성 검정을 실시하였다. 한 영역에 하나의 항목 만 존재하는 경우, 서열척도로 판단하여 정규성 검정을 실시하 지 않았다. 두 개 이상의 항목으로 평가된 영역은 등간척도이기 때문에, 모수 통계 검정을 사용할 수 있는지 파악하고자 정규 성 검정을 실시하였다. 그 결과, 모든 영역에 대한 $p$ 값이 0.05 미 만으로 나타났다. 즉 정규성 가정을 만족한다는 귀무가설을 기 각하므로 모든 영역의 점수는 정규분포를 따르지 않는 것으로 판단하였다.

둘째, 종속변수의 정규성 검정 결과 정규분포를 따르지 않는 것으로 나타났기 때문에 말더듬성인과 일반성인의 조음기관 
구조 및 기능에 유의한 차이가 있는지 확인하기 위해 비모수 통계 검정 방법 중 하나인 윌콕슨의 순위합 검정(Wilcoxon's rank sum test)을 실시하였다.

셋째, 말더듬 중증도와 조음기관 구조 및 기능의 각 영역 간 의 상관관계를 파악하기 위해 비모수 통계 검정 방법 중 하나인 스피어만의 상관관계 분석(Spearman's correlation analysis)을 실시하였다. 수집한 자료에 대한 통계분석은 SPSS for Windows v22.0(SPSS Inc., Chicago, IL, USA) 프로그램을 이용하 여 처리하였고, 유의수준 0.05 를 기준으로 분석하였다.

\section{RESULTS}

\section{말더듬성인과 일반성인의 영역별 조음기관 구조}

말더듬성인과 일반성인의 조음기관 구조를 비교하기 위해, 우선 중위수를 산출하였다. 그 결과 얼굴, 입술, 인두, 호흡 영 역 구조는 말더듬성인과 일반성인 모두 최고점 2점으로 평가되 었으며, 집단 간 차이는 없었다. 한편 턱과 치아는 말더듬성인의 중위수가 1점 높았지만, 윌콕슨의 순위합 검정(Wilcoxon's rank sum test)을 실시한 결과, 유의한 차이가 나타나지 않았다. 즉 일반성인과 말더듬성인은 조음기관 구조 모든 영역에서 유의한 차이가 없는 것으로 나타났다. 말더듬성인과 일반성인의 조음 기관 구조 점수의 중위수(Table 1)와 말더듬성인과 일반성인의
조음기관 구조 차이를 검증하였다(Table 2).

\section{말더듬성인과 일반성인의 영역별 조음기관 기능}

말더듬성인과 일반성인의 조음기관 기능을 비교하기 위해, 중위수를 산출하였다. 그 결과 턱과 치아 영역 기능과 인두 영 역 기능은 말더듬성인과 일반성인 모두 최고점 2점으로 평가되 었으며, 집단 간 차이는 없었다. 한편 얼굴 영역 기능, 입술 영역 기능, 혀 영역 기능, 경구개 및 연구개 영역 기능, 호흡 영역 기능 모두 중위수에서 차이를 보이지 않았으며, 윌콕슨의 순위합 검 정 결과에서 역시 유의한 차이를 보이지 않았다. 즉 일반성인과 말더듬성인은 조음기관 기능 전 영역에 유의한 차이가 없는 것 으로 나타났다. 추가적으로 우성유전법칙이 적용되는 '혀 말기' 나 ‘혀 좁히기'와 같은 항목을 제외한 혀 영역 기능 점수를 추가 로 비교하였다. 우성유전법칙이 적용되는 항목을 제외하여 추 가로 집단 간 비교를 실시한 이유는 우성유전법칙이 적용되는 항목은 유전적인 부분으로 해당 항목들을 포함한 결과만을 비 교했을 때 결과 해석에 있어 오류를 일으킬 위험이 있기 때문이 다. 말더듬성인과 일반성인의 조음기관 기능 점수의 중위수 (Table 3)와 말더듬성인과 일반성인의 조음기관 기능 차이를 제 시하였다(Table 4). 또한, 말더듬성인과 일반성인의 개인별 $\mathrm{SMST}$ 점수가 제시되어 있다(Appendices $2 \& 3$ ).

Table 1. Median of speech mechanism score

\begin{tabular}{|c|c|c|c|c|c|}
\hline \multirow{2}{*}{ Speech mechanism } & \multirow{2}{*}{ Range } & \multicolumn{2}{|c|}{ AWS ( $\mathrm{n}=17)$} & \multicolumn{2}{|c|}{ AWNS ( $\mathrm{n}=17)$} \\
\hline & & Median & IQR & Median & $\mathrm{IQR}$ \\
\hline Facial & $0-2$ & 2.00 & 0.00 & 2.00 & 0.00 \\
\hline Lips & $0-2$ & 2.00 & 0.00 & 2.00 & 0.00 \\
\hline Tongue & $0-4$ & 4.00 & 0.00 & 4.00 & 0.00 \\
\hline Jaw and tooth & $0-6$ & 6.00 & 1.00 & 5.00 & 2.50 \\
\hline Hard palate and soft palate & $0-8$ & 8.00 & 0.50 & 8.00 & 1.00 \\
\hline Pharynx & $0-2$ & 2.00 & 0.00 & 2.00 & 0.00 \\
\hline Breathing & $0-2$ & 2.00 & 0.00 & 2.00 & 0.00 \\
\hline Total & $0-26$ & 25.00 & 1.00 & 24.00 & 3.00 \\
\hline
\end{tabular}

AWS: adults who stutter, AWNS: adults who do not stutter, IQR: interquartile range

Table 2. Difference verification of speech mechanism score (Wilcoxon rank sum test)

\begin{tabular}{|c|c|c|c|c|c|c|}
\hline \multirow{2}{*}{ Speech mechanism } & \multicolumn{2}{|c|}{ AWS $(n=17)$} & \multicolumn{2}{|c|}{ AWNS $(n=17)$} & \multirow{2}{*}{$\mathrm{Z}$} & \multirow{2}{*}{$p$} \\
\hline & Mean rank & Rank sum & Mean rank & Rank sum & & \\
\hline Facial & 17.50 & 297.50 & 17.50 & 297.50 & 0.000 & 1.000 \\
\hline Lips & 17.50 & 297.50 & 17.50 & 297.50 & 0.000 & 1.000 \\
\hline Tongue & 17.00 & 289.00 & 18.00 & 306.00 & 1.000 & 0.317 \\
\hline Jaw and tooth & 20.32 & 345.50 & 14.68 & 249.50 & 1.758 & 0.079 \\
\hline Hard palate and soft palate & $0-8$ & 306.00 & 17.00 & 289.00 & 0.383 & 0.702 \\
\hline Pharynx & 17.50 & 297.50 & 17.50 & 297.50 & 0.000 & 1.000 \\
\hline Breathing & 17.50 & 297.50 & 17.50 & 297.50 & 0.000 & 1.000 \\
\hline Total & 19.62 & 333.50 & 15.38 & 261.50 & 1.283 & 0.199 \\
\hline
\end{tabular}

AWS: adults who stutter, AWNS: adults who do not stutter 
Table 3. Median of oral motor abilities score

\begin{tabular}{|c|c|c|c|c|c|}
\hline \multirow{2}{*}{ Oral motor abilities } & \multirow{2}{*}{ Range } & \multicolumn{2}{|c|}{ AWS $(n=17)$} & \multicolumn{2}{|c|}{ AWNS $(n=17)$} \\
\hline & & Median & IQR & Median & IQR \\
\hline Facial & $0-2$ & 2.00 & 0.00 & 2.00 & 0.00 \\
\hline Lips & $0-8$ & 8.00 & 0.00 & 8.00 & 0.00 \\
\hline Tongue & $0-12$ & 12.00 & 1.50 & 12.00 & 1.50 \\
\hline Tongue (except dominant inheritance) & $0-8$ & 8.00 & 0.00 & 8.00 & 0.00 \\
\hline Jaw and tooth & $0-2$ & 2.00 & 0.00 & 2.00 & 0.00 \\
\hline Hard palate and soft palate & $0-4$ & 4.00 & 2.00 & 4.00 & 1.00 \\
\hline Pharynx & $0-2$ & 2.00 & 0.00 & 2.00 & 0.00 \\
\hline Breathing & $0-4$ & 4.00 & 0.00 & 4.00 & 0.00 \\
\hline Total & $0-34$ & 29.00 & 2.00 & 30.00 & 2.00 \\
\hline
\end{tabular}

AWS: adults who stutter, AWNS: adults who do not stutter, IQR: interquartile range

Table 4. Difference verification of oral motor abilities score (Wilcoxon rank sum test)

\begin{tabular}{|c|c|c|c|c|c|c|}
\hline \multirow{2}{*}{ Oral motor abilities } & \multicolumn{2}{|c|}{ AWS $(n=17)$} & \multicolumn{2}{|c|}{ AWNS $(n=17)$} & \multirow{2}{*}{$\mathrm{Z}$} & \multirow[b]{2}{*}{$p$} \\
\hline & Mean rank & Rank sum & Mean rank & Rank sum & & \\
\hline Facial & 18.00 & 306.00 & 17.00 & 289.00 & 0.596 & 0.551 \\
\hline Lips & 18.00 & 306.00 & 17.00 & 289.00 & 1.000 & 0.317 \\
\hline Tongue & 17.15 & 291.50 & 17.85 & 303.50 & 0.250 & 0.803 \\
\hline Tongue (except dominant inheritance) & 17.06 & 290.00 & 17.94 & 305.00 & 0.525 & 0.600 \\
\hline Jaw and tooth & 17.50 & 297.50 & 17.50 & 297.50 & 0.000 & 1.000 \\
\hline Hard palate and soft palate & 17.00 & 289.00 & 18.00 & 306.00 & 0.383 & 0.702 \\
\hline Pharynx & 17.50 & 297.50 & 17.50 & 297.50 & 0.000 & 1.000 \\
\hline Breathing & 16.00 & 272.00 & 19.00 & 323.00 & 1.785 & 0.074 \\
\hline Total & 15.91 & 270.50 & 19.09 & 324.50 & 0.988 & 0.323 \\
\hline
\end{tabular}

AWS: adults who stutter, AWNS: adults who do not stutter

\section{말더듬 중증도와 조음기관 구조 간 상관성}

말더듬성인의 말더듬 중증도(P-FA-II 점수)와 조음기관 구 조 점수 간 상관성을 검증하기 위해, 비모수 상관관계 분석인 스피어만의 상관관계 분석(Spearman's correlation analysis)을 실시하였다. 얼굴 영역 구조, 입술 영역 구조, 인두 영역 구조, 호흡 영역 구조는 모든 참가자가 최고점으로 나타났기 때문에 상관계수가 산출되지 않았다. 그리고 혀 영역 구조와 말더듬 중 증도는 상관관계가 없는 것으로 나타났으며 $(r=0.000, p>0.05)$, 턱과 치아 영역 구조 $(r=-0.144, p>0.05)$, 경구개 및 연구개 영 역 구조 $(r=-0.311, p>0.05)$ 는 말더듬 중증도와 부적 상관관 계를 보였지만 통계적으로 유의하지 않았다.

한편 조음기관 구조 총점과 말더듬 중증도의 상관계수를 산 출한 결과, 부적 상관관계를 보였으나 역시 통계적으로 유의하 지는 않았다 $(r=-0.388, p>0.05)$. 말더듬 중증도와 조음기관 구조 점수 간 상관성 검정 결과를 표로 제시하였다(Table 5).

\section{말더듬 중증도와 조음기관 기능 간 상관성}

말더듬성인의 말더듬 중증도(P-FA-II 점수)와 조음기관 기 능 점수 간 상관성을 검증하기 위해 스피어만의 상관관계 분석 을 실시하였다.
입술 영역 기능, 턱과 치아 영역 기능, 인두 영역 기능은 모든 대상자가 최고점으로 나타났기 때문에 상관계수를 산출하지 않았다. 얼굴 영역 기능은 말더듬 중증도와 부적 상관관계를 보였지만 유의하지는 않았으며 $(r=-0.306, p>0.05)$, 혀 영역 기능은 말더듬 중증도와 유의한 부적 상관관계를 보였다 $(r=$ $-0.563, p<0.05)$. 즉 말더듬 중증도가 심할수록 혀 영역 기능 은 떨어지는 것으로 판단되었다. 그러나 혀 영역 기능에서, 우성 유전법칙이 적용되는 두 개의 항목('혀 말기', '혀 좁히기')이 결 과에 영향을 줄 수 있음을 배제하기 위하여 이 항목들을 제외 하고 상관성을 검증해보았는데, 그 결과, 혀 영역 역시 말더듬 중증도와 유의한 상관관계가 없는 것으로 나타났다 $(r=0.037$, $p>0.05)$. 경구개 및 연구개 영역 기능은 정적 상관관계를 보 였으나 유의하지는 않았으며 $(r=0.132, p>0.05)$, 호흡 영역 기 능은 말더듬 중증도와 부적 상관관계를 보였지만 유의하지는 않았다 $(r=-0.352, p>0.05)$.

한편 조음기관 기능 총점과 말더듬 중증도의 상관계수를 산 출한 결과, 부적 상관관계를 보였지만 통계적으로 유의하지는 않았다 $(r=-0.282, p>0.05)$. 말더듬 중증도와 조음기관 기능 점수 간 상관성 검정 결과를 표로 제시하였다(Table 6). 
Table 5. Correlation between stuttering severity and speech mechanism score

\begin{tabular}{lcc}
\hline \multicolumn{1}{c}{ Speech mechanism } & The correlation coefficient between stuttering severity & $p$ \\
\hline Facial & - & - \\
Lips & 0.000 & 1.000 \\
Tongue & -0.144 & 0.582 \\
Jaw and tooth & -0.311 & 0.224 \\
Hard palate and soft palate & - & - \\
Pharynx & -0.388 & 0.124 \\
Breathing & \\
Total &
\end{tabular}

Table 6. Correlation between stuttering severity and oral motor abilities score

\begin{tabular}{lcc}
\hline \multicolumn{1}{c}{ Oral motor abilities } & The correlation coefficient between stuttering severity & $p$ \\
\hline Facial & -0.306 & 0.232 \\
Lips & - & $0.563^{*}$ \\
Tongue & 0.037 & 0.019 \\
Tongue (except dominant inheritance) & - & 0.887 \\
Jaw and tooth & 0.132 & 0.614 \\
Hard palate and soft palate & - & 0.165 \\
Pharynx & -0.352 & 0.274 \\
Breathing & -0.282 & \\
Total &
\end{tabular}

${ }^{*} p<0.05$

\section{DISCUSSIONS}

본 연구에서는 조음기관 구조 및 기능을 직접 관찰하여 평가 하는 조음기관 구조·기능 선별검사(SMST) (Shin et al., 2010)의 '조음기관 구조 및 기능' 검사의 일부분을 사용하여 말더듬성인 의 조음기관 구조 및 기능에서 일반성인과 차이가 있는지 알아 보았다. 또한, 말더듬성인의 조음기관 구조 및 기능 점수와 말 더듬 중증도 간 상관성을 확인하였다. 본 연구는 이러한 결과 가 말더듬는 사람의 조음기관 구조 및 기능 평가와 이에 따른 중재에 어떠한 의미를 주는지에 대하여 논의하고자 하였다.

\section{말더듬성인의 조음기관 구조 및 기능}

본 연구에서 사용한 직접적인 방식의 조음기관 구조 및 기능 검사에서 얼굴, 입술, 혀, 턱과 치아, 경구개 및 연구개, 인두, 호 흡 영역 모두 말더듬성인 집단과 일반성인 집단 간 유의한 차 이가 나타나지 않았다. 영역별 비교뿐만 아니라 조음기관 구조 총점, 그리고 기능 총점에서도 유의한 차이는 나타나지 않았다. 이러한 결과로 미루어 볼 때, 적어도 본 연구에서 사용한 직접 적인 방식의 검사로는 집단 간 차이를 명확히 확인하기 어려워 보인다. 이는 직접적인 검사는 아니지만, 구어적 수준에서 나타 나는 양상을 토대로 구강운동능력을 비교한 몇몇 선행 연구 결 과와 일치한다(Caruso et al., 1988; Conture et al., 1988). 그들 의 연구는 비구어적 수준이 아닌 구어적 수준에서 나타나는
구강운동능력을 비교했다는 점에서 본 연구와 다르지만, 이번 연구 결과를 통해 도출된 두 그룹 간 차이가 없다는 결론에 있 어서는 유사하다.

그러나 본 연구 결과는 말더듬는 사람이 말을 더듬지 않는 사람보다 구강운동능력이 취약하다고 보고한 다수의 선행연구 결과와 상반된다(Alpermann \& Zückner, 2008; Cook et al., 2011; Hutchinson \& Watkin, 1976; Riley \& Riley, 1979; Riley \& Riley, 1986; Riley \& Riley, 2000; Smith, 1999; Van Lieshout et al., 1996). 말더듬는 사람의 낮은 구강운동능력을 보고한 여러 선행 연구와 본 연구 결과가 상이한 이유에 대해 고찰해볼 필요가 있다. 말더듬 이론에서 비교적 최근 모델로 볼 수 있는 내적수정가설(Covert repair hypothesis) (Postma \& Kolk, 1993)과 EXPLAN모델(Execution and Planning model) (Howell, 2004)은 음운적인 단계에서 나타나는 문제 즉 말 산 출 이전에 음운적으로 부호화하는 단계에서 나타나는 문제가 말더듬을 유발한다고 설명한다. 이러한 이론에 따르면 언어적 과업이 포함되지 않은 단순한 조음기관 구조 및 기능 평가에서 는 말더듬는 사람과 말을 더듬지 않는 사람 간 일반적인 차이 를 관찰하기 어려울 수도 있다.

이러한 측면을 고려하여 최근에는, 대체로 말더듬는 사람의 운동적 차이를 보기 위해 단순한 구조나 기능의 문제를 보기보 다는 구어를 산출할 때 관찰할 수 있는 구강운동의 협응 문제 를 주로 다룬다(Alpermann \& Zückner, 2008; Howell et al., 
2009; Namasivayam \& Van Lieshout, 2008; Smith \& Kleinow, 2000). 그러나 이러한 노력들에 있어서 주요한 어려움 중 하나 는 무엇이 정상 운동 협응의 구성요소인지에 관한 공통된 의견 이 부족하다는 것이었다(Caruso et al., 1988). 또한, 이러한 연구 들은 대체로 언어적 과정이 포함된 과제에서 나타난 결과를 토 대로 구강운동능력의 결함을 추측해야 한다는 한계가 있다.

그러나, Howell(2010)은 운동적인 요소가 말더듬에 영향을 준다는 사실을 분명히 증명하기 위해서는 말더듬이 언어적 과 정에서 발생한 부수적인 결과가 아니라는 사실을 확실히 밝힐 필요가 있다고 강조하였다. 말더듬는 사람의 구강운동능력을 평가할 때 언어적인 요소가 개입된다면 언어적 과정과 운동 과 정이 상호작용할 수밖에 없다. 본 연구에서는 이러한 점을 배제 하기 위해 순수하게 비구어적인 방식으로만 검사를 진행하였 다. 언어적 과정이 개입되지 않은 비구어적인 형태로만 말더듬 는 사람의 구강운동능력이 평가되어야 한다는 연구의 필요성 은 오래전부터 지적되어 왔으나(Caruso et al., 1988) 순수하게 비구어적인 방식을 사용하면서, 과학적이고 객관적인 형태로 구 강운동능력을 검사하는 연구 실시에 대한 어려움으로 인해 그 러한 연구는 많이 시도되지 못하였다.

이와 같은 제한점을 보완하기 위하여 Cook et al.(2011)은 비 구어적인 방식으로 조음기관 구조 및 기능을 직접 관찰하여 실 험을 실시하였으며, 이는 본 연구에서 시도한 방법과 부분적으 로 일치한다. 본 연구의 결과와 그들의 연구 결과가 상이한 이 유에 대해서 몇 가지 논의하자면 다음과 같다. 먼저 연구 설계 에 있어서 두 연구의 차이점이 있었는데, Cook et al.(2011)의 연구에서는 대체로 나이가 어린 대상자(평균연령: 13세, 연령범 위: 9 20세)를 상대로 실험을 진행한 반면, 본 연구에서는 성인 (평균연령: 32세, 연령범위: 19 57세)을 대상으로 실험을 진행했 다. 구강운동능력은 나이가 듦에 따라 발달하므로 이러한 차이 가 상이한 결과를 낳았을 가능성이 있다. 하지만 구강운동능력 이 9 세에서 14 세 사이에 성인의 기능적인 수준까지 도달하게 된 다는 기존 연구 결과(Smith \& Zelaznik, 2004; Yaruss \& Logan, 2002)를 감안하면, 연령 차이만으로 다른 결과가 도출되었 다고 보는 데는 무리가 있다. 또 다른 점은 점수 체계에서 Cook et al.(2011)은 2점 척도(정상: 1점, 비정상: 0점)를 사용했으며 본 연구에서는 3점 척도(정상: 2점, 약간 비정상: 1점, 심각한 비정상: 0점)를 사용했다는 점, 그리고 두 연구 모두 비구어적 인 수준에서 검사가 진행됐지만, 검사 항목이 조금씩 다르기 때문에 상이한 연구 결과가 비롯됐을 가능성이 있다.

\section{말더듬 중증도와 조음기관 구조 및 기능 간 상관성}

말더듬성인 집단에서 나타나는 말더듬 중증도와 조음기관 구조의 각 영역 간 상관성 및 말더듬 중증도와 조음기관 기능
의 각 영역 간 상관성을 알아본 결과, 모든 영역에서 상관성이 나타나지 않았다. 그러나 개인차가 존재한다는 것은 간과해서는 안 될 것이다. 만일 이러한 기초적인 수준에서의 구강운동능력 에 문제가 있는 사람이라면 부드러운 말 산출을 하는 데 어려움 이 있을 수 있기 때문이다. 즉 이러한 기초적인 문제는 유창성에 영향을 줄 수 있다. 앞선 여러 연구에서 특히 아동기에 이 영역 에서의 취약성이 지적되었는데 어떤 경우에는 성인기에 이러한 문제가 직접 관찰로는 발견되지 않을 정도로 회복이 되었을 가 능성이 있다(Smith \& Zelaznik, 2004; Yaruss \& Logan, 2002). 또한, 이러한 기제에는 명백한 차이가 없으나 심리-언어적인 부 분 등과 같은 좀 더 상위 과정과 연결되는 과정에서 어려움을 가질 수도 있다.

만일 차이가 존재한다면 이를 밝히기 위해서는 보다 정교한 관찰 방법이 필요할 것이다. 그리고 말더듬 평가를 진행하는 과 정에서 해당 부분에 대해 평가하지 않고, 이러한 문제를 무시 한다면 이는 말더듬 중증도 혹은 개인차에 따라서 치료 효과 를 늦추거나 제한하는 결과를 낳을 수 있다. 말더듬는 사람의 경우, 말 산출 기제의 기초적인 영역에서 문제의식을 가지고 있 는 경우가 있는데(Shin \& Seong, 2007), 이들에게 말 산출 기 제의 기초 영역에 대한 정확한 검사결과를 제공함으로써 막연 한 불안감을 해소하는 데 도움을 줄 수 있어야 한다. 즉, 조음기 관의 구조 및 기능에 제한이 없는데도 해당 영역에 대해 막연 한 불안감을 가지고 있는 사람이라면 이 역시 말더듬을 가중 하는 요소로 작용할 수 있기 때문이다. 임상가는 조음기관의 구조 및 기능 검사를 통해 대상자에게 정확한 정보를 제공할 필요가 있다. 본 연구는 향후 과학적이고 객관적인 형태의 기기 를 사용하여 구강운동능력을 검사하는 연구가 이루어지는 데 기초적인 자료로 활용될 수 있다는 데 의의가 있다. 향후 본 연 구에서처럼 언어적 과정이 포함되지 않은 직접적인 방식으로 말더듬는 사람의 구강운동능력을 보다 세밀하게 살필 수 있는 후속연구가 실시되기를 기대한다.

중심 단어 : 말 기제·구강운동능력·말더듬.

\section{REFERENCES}

Alpermann, A. \& Zückner, H. (2008). Speech motor skills of stuttering children. Sprache Stimme Gehor, 32(1), 36-40.

Anderson, J. D. \& Conture, E. G. (2000). Language abilities of children who stutter: A preliminary study. Journal of Fluency Disorders, 25(4), 283-304.

Caruso, A. J., Abbs, J. H., \& Gracco, V. L. (1998). Kinematic analysis of multiple movement coordination during speech in stutterers. Brain, 111 (Pt 2), 439-456.

Conture, E. G., Colton, R. H., \& Gleason, J. R. (1988). Selected temporal aspects of coordination during fluent speech of young stutterers. Journal of Speech, Language, and Hearing Research, 31(4), 640-653.

Cook, S., Rieger, M., Donlan, C., \& Howell, P. (2011). Testing orofacial 
abilities of children who stutter: The movement, articulation, mandibular and sensory awareness (MAMS) assessment procedure. Journal of Fluency Disorders, 36(1), 27-40.

Craig, A., Hancock, K., Tran, Y., Craig, M., \& Peters, K. (2002). Epidemiology of stuttering in the community across the entire life span. Journal of Speech, Language, and Hearing Research, 45(6), 1097-1105.

Dworkin, J. \& Culatta, R. (1996). Dworkin-culatta oral mechanism examtreatment (D-COME-T). Nicholasville, KY: Edgewood Press.

Dworzynski, K., Howell, P., \& Natke, U. (2003). Predicting stuttering from linguistic factors for German speakers in two age groups. Journal of Fluency Disorders, 28(2), 95-112.

Howell, P. (2004). Assessment of some contemporary theories of stuttering that apply to spontaneous speech. Contemporary Issues in Communication Sciences and Disorders, 31, 123-140.

Howell, P. (2010). Recovery from stuttering. New York: Psychology Press.

Howell, P., Anderson, A. J., Bartrip, J., \& Bailey, E. (2009). Comparison of acoustic and kinematic approaches to measuring utterance-level speech variability. Journal of Speech, Language, and Hearing Research, 52(4), 1088-1096.

Hutchinson, J. M. \& Watkin, K. L. (1976). Jaw mechanics during release of the stuttering moment: Some initial observations and interpretations. Journal of Communication Disorders, 9(4), 269-279.

Louis, K. O. \& Ruscello, D. (2000). Oral speech mechanism screening examination (3rd ed.). Austin, TX: Pro-Ed.

Marshalla, P. (2008). Marshalla oral sensorimotor test: MOST. Greenville, SC: Super Duper Publications.

Namasivayam, A. K. \& van Lieshout, P. (2008). Investigating speech motor practice and learning in people who stutter. Journal of Fluency Disorders, 33(1), 32-51.

Postma, A. \& Kolk, H. (1993). The covert repair hypothesis: prearticulatory repair processes in normal and stuttered disfluencies. Journal of Speech and Hearing Research, 36(3), 472-487.

Riley, G. \& Riley, J. (1979). A component model for diagnosing and treating children who stutter. Journal of Fluency Disorders, 4(4), 279-293.

Riley, G. \& Riley, J. (1986). Oral motor discoordination among children who stutter. Journal of Fluency Disorders, 11(4), 334-335.
Riley, G. \& Riley, J. (2000). A revised component model for diagnosing and treating children who stutter. Contemporary Issues in Communication Sciences and Disorders, 27(2), 188-199.

Robbins, J. \& Klee, T. (1987). Clinical assessment of oropharyngeal motor development in young children. The Journal of Speech and Hearing Disorders, 52(3), 271-277.

Shin, M. J. \& Seong, J. N. (2007). The treatment of stuttering adults in practice. The 10th International Stuttering Awareness Day: Workshop for assessment and treatment of stuttering adults. Seoul: Korean Association of Speech-Language Pathologists.

Shin, M. J., Kim, J. O., Lee, S. B., \& Lee, S. Y. (2010). Speech Mechanism Screening Test. Seoul: Hakjisa.

Shipley, K. G. \& McAfee, J. G. (2008). Assessment in speech-language pathology: A resource manual (4th ed.). Clifton Park, NY: Delmar Cengage Learning.

Sim, H. S., Shin, M. J., \& Lee, E. J. (2010). Paradise-Fluency Assessment-II. Seoul: Paradise Welfare Foundation.

Smith, A. \& Kleinow, J. (2000). Kinematic correlates of speaking rate changes in stuttering and normally fluent adults. Journal of Speech, Language, and Hearing Research, 43(2), 521-536.

Smith, A. \& Zelaznik, H. N. (2004). Development of functional synergies for speech motor coordination in childhood and adolescence. Developmental Psychobiology, 45(1), 22-33.

Smith, A. (1999). Stuttering: A unified approach to a multifactorial, dynamic disorder. In N. B. Ratner \& E. C. Healey. Stuttering Research and Practice: Bridging the Gap (pp. 27-44). Mahwah, NJ: Lawrence Erlbaum.

Starkweather, C. W. \& Gottwald, S. R. (1990). The demands and capacities model II: Clinical applications. Journal of Fluency Disorders, 15(3), 143157.

van Lieshout, P. H., Hulstijn, W., \& Peters, H. F. (1996). Speech production in people who stutter: Testing the motor plan assembly hypothesis. Journal of Speech and Hearing Research, 39(1), 76-92.

Yaruss, J. S. \& Logan, K. J. (2002). Evaluating rate, accuracy, and fluency of young children's diadochokinetic productions: A preliminary investigation. Journal of Fluency Disorders, 27(1), 65-85; quiz 85-86. 


\section{APPENDIX}

Appendix 1. SMST (Structure and function of articulator)

0 = severe abnormal, 1 = a little bit abnormal, 2 = normal

\begin{tabular}{|c|c|c|c|c|c|c|c|c|}
\hline \multirow{2}{*}{$\begin{array}{l}\text { Articulator } \\
\text { 얼굴 }\end{array}$} & \multirow{2}{*}{$\begin{array}{c}\text { Instruction } \\
\text { 얼굴에 힘을 주지 말고 편안하게 있으세요. }\end{array}$} & \multirow{2}{*}{$\begin{array}{l}\text { Assignment } \\
\text { - 휴식상태에서의 모양/좌우 대칭성/ } \\
\text { 구순 여부 }\end{array}$} & \multicolumn{3}{|c|}{ Structure } & \multicolumn{3}{|c|}{ Function } \\
\hline & & & 0 & 12 & 2 & & & \\
\hline & $\begin{array}{l}\text { 눈을 감았다 떠보세요. } \\
\text { 눈썹을 위로 올려 보세요. } \\
\text { 얼굴을 찌푸려 보세요. }\end{array}$ & - 움직임 & & & & 0 & 1 & 2 \\
\hline \multirow[t]{5}{*}{ 입술 } & 입을 다물고 앞을 보세요. & $\begin{array}{l}\text { - 휴식상태에서의 모양/좌우 대칭성/ } \\
\text { 구순 여부 }\end{array}$ & 0 & 1 & 2 & & & \\
\hline & 뽀뽀하는 흉내를 내세요. & - 입술을 앞으로 내밀며 둥글게 하기 & & & & 0 & 1 & 2 \\
\hline & 입을 다물고 볼을 부풀려 보세요. & - 입술을 닫고 양볼을 부풀게 하기 & & & & 0 & 1 & 2 \\
\hline & $\begin{array}{l}\text { 입술을 다물고 입술의 양끝을 뒤쪽으로 당겨 } \\
\text { 보세요. }\end{array}$ & - 입술의 양끝을 뒤쪽으로 잡아당기기 & & & & 0 & 1 & 2 \\
\hline & 윗니로 아랫입술을 물어보세요. & - 아랫입술 물기 & & & & 0 & 1 & 2 \\
\hline \multirow[t]{8}{*}{ 혀 } & 혀를 최대한 밖으로 내미세요. & • 표면색깔 및 크기 & 0 & 12 & 2 & & & \\
\hline & $\begin{array}{l}\text { 혀를 내밀어서 왼쪽-오른쪽으로 왔다갔다 } \\
\text { 움직여 보세요. }\end{array}$ & - 혀끝을 내밀어 왼쪽-오른쪽으로 하기 & & & & 0 & 1 & 2 \\
\hline & $\begin{array}{l}\text { 입을 최대한 크게 벌리고 혀끝을 입천장에 } \\
\text { 대세요. }\end{array}$ & - 설소대 길이 & 0 & 1 & 2 & & & \\
\hline & 혀끝을 위로 올려 윗니 뒤에 붙이세요. & $\begin{array}{l}\text { - 혀끝을 내밀어 위로 올리기 혹은 } \\
\text { 혀끝을 위로 올려 치조에 대기 }\end{array}$ & & & & 0 & 1 & 2 \\
\hline & $\begin{array}{l}\text { 입을 벌리고 혀끝을 윗니 뒤에서부터 목젖을 } \\
\text { 따라 뒤쪽으로 당겨보세요. }\end{array}$ & $\begin{array}{l}\text { - 혀끝을 경구개를 따라 뒤쪽으로 끌어 } \\
\text { 당기기 }\end{array}$ & & & & 0 & 1 & 2 \\
\hline & 혀끝으로 설압자를 밀어보세요. & - 혀끝으로 설압자 밀기 & & & & 0 & 1 & 2 \\
\hline & 혀를 앞에서 뒤로 말아보세요. & - 혀를 뒤로 말기 & & & & 0 & 1 & 2 \\
\hline & 혀의 양쪽을 말아서 좁혀보세요. & - 혀를 내밀어 말아서 좁히기 & & & & 0 & 1 & 2 \\
\hline \multirow[t]{4}{*}{ 턱과 치아 } & 어금니를 물고 /으/, /이/ 소리를 내세요. & $\begin{array}{l}\text { - 중앙 앞니의 교합 } \\
\text { (open bite, deep bite, overjet+, } \\
\text { overjet-) }\end{array}$ & 0 & 1 & 2 & & & \\
\hline & & • 치아의 맞물림(Class I, II, III) & 0 & 12 & 2 & & & \\
\hline & $\begin{array}{l}\text { 어금니에서 딱딱 소리가 나도록 어금니를 } \\
\text { 부딪혀보세요. }\end{array}$ & - 어금니 부딪히기(교근운동) & & & & 0 & 1 & 2 \\
\hline & 입을 크게 벌려 보세요. & - 치아 상태 & 0 & 1 & 2 & & & \\
\hline 경구개 및 & 입을 크게 벌려 보세요. & - 경구개의 색깔 및 주름 상태 & 0 & 12 & 2 & & & \\
\hline \multicolumn{9}{|l|}{ 연구개 } \\
\hline & & • 입천장 높이 및 넓이 & 0 & 1 & 2 & & & \\
\hline & & - 구개편도의 여부 및 크기 & 0 & 1 & 2 & & & \\
\hline & & $\begin{array}{l}\text { - 연구개와 목젖의 휴식상태에서의 } \\
\text { 모양/좌우 대칭성 }\end{array}$ & 0 & & 2 & & & \\
\hline
\end{tabular}




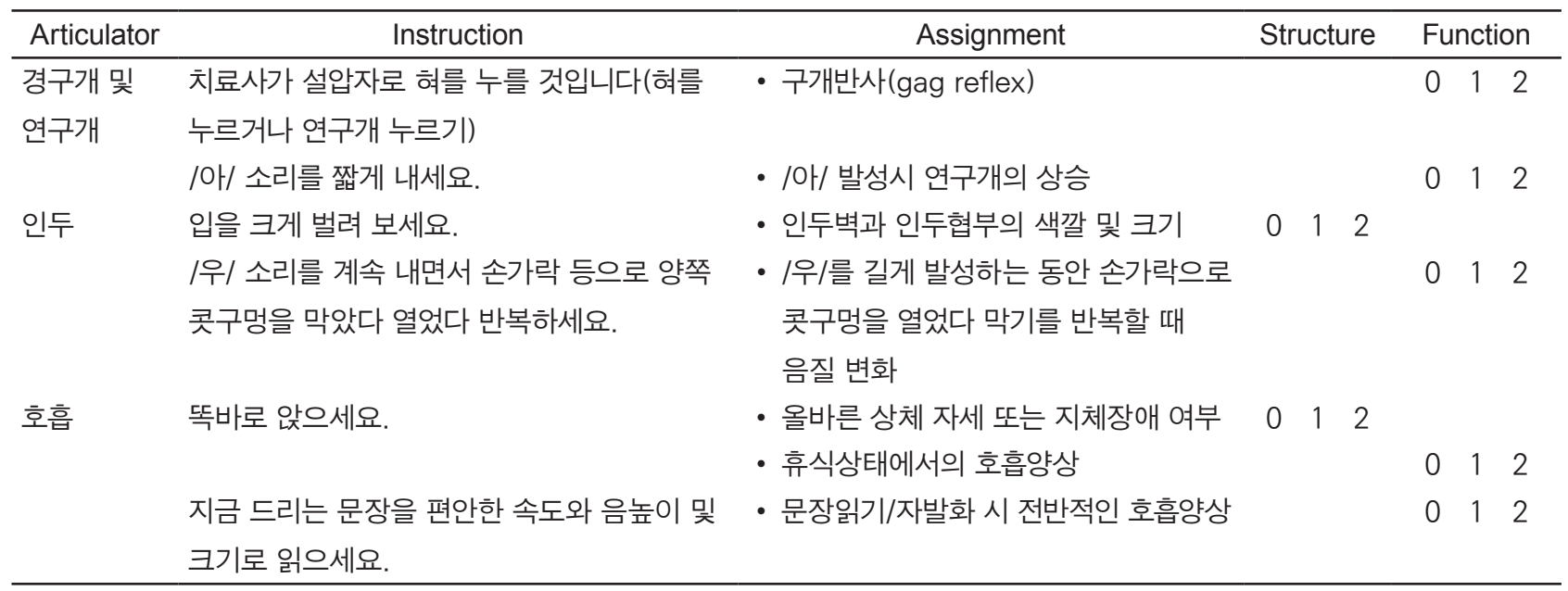


Appendix 2. Individual data of adlts with stuttering problem

Structure $=$ Total points $: 26$ scores, Function $=$ Total points $: 34$ scores

\begin{tabular}{|c|c|c|}
\hline Number & Age & Score of SMST \\
\hline \multirow[t]{2}{*}{$S-1(f)$} & $51: 2$ & 구조 26 \\
\hline & & 기능 34 \\
\hline \multirow[t]{2}{*}{ S-2 } & $57: 9$ & 구조 25(교합 1점) \\
\hline & & 기능 34 \\
\hline \multirow[t]{2}{*}{ S-3 } & $30: 1$ & 구조 26 \\
\hline & & 기능 32(구개반사 0점) \\
\hline \multirow[t]{2}{*}{$S-4$} & $39: 9$ & 구조 26 \\
\hline & & 기능 34 \\
\hline \multirow[t]{2}{*}{$S-5$} & $22: 7$ & 구조 25(앞니 1점) \\
\hline & & 기능 34 \\
\hline \multirow[t]{2}{*}{$S-6$} & $23: 1$ & 구조 26 \\
\hline & & 기능 32(구개반사 0점) \\
\hline \multirow[t]{2}{*}{$S-7(f)$} & $29: 5$ & 구조 26 \\
\hline & & 기능 32(구개반사 0점) \\
\hline \multirow[t]{2}{*}{$S-8$} & $24: 7$ & 구조 22(앞니 1점, 교합 1점, 치아 1점, 입천장 1점) \\
\hline & & 기능 31(혀 밀기 1점, 구개반사 0점) \\
\hline \multirow[t]{2}{*}{$S-9$} & $19: 11$ & 구조 25(설소대 1점) \\
\hline & & 기능 31(혀거상 1점, 혀말기 1점, 혀좁히기 1점) \\
\hline \multirow[t]{2}{*}{ S-10 } & $26: 10$ & 구조 25(목젖 1점) \\
\hline & & 기능 34 \\
\hline \multirow[t]{2}{*}{ S-11 } & $32: 9$ & 구조 26 \\
\hline & & 기능 32(혀말기 1점, 호흡 1점) \\
\hline \multirow[t]{2}{*}{ S-12 } & $38: 8$ & 구조 25(목젖 1점) \\
\hline & & 기능 34 \\
\hline \multirow[t]{2}{*}{ S-13 } & $42: 7$ & 구조 20(앞니 0점, 교합 0점, 치아 0점) \\
\hline & & 기능 33(호흡 1점) \\
\hline \multirow[t]{2}{*}{ S-14 } & $32: 11$ & 구조 22(앞니 0점, 교합 0점) \\
\hline & & 기능 32(호흡 0점) \\
\hline \multirow[t]{2}{*}{ S-15 } & $23: 2$ & 구조 25(교합 1점) \\
\hline & & 기능 31(눈썹 1점, 혀말기 1점, 혀좁히기 1점) \\
\hline \multirow[t]{2}{*}{ S-16(f) } & $40: 1$ & 구조 26 \\
\hline & & 기능 30(혀말기 1점, 혀좁히기 1점, 구개반사 0점) \\
\hline \multirow[t]{2}{*}{ S-17 } & $23: 10$ & 구조 25(목젖 1점) \\
\hline & & 기능 32(혀말기 1점, 혀좁히기 1점) \\
\hline
\end{tabular}




\section{Appendix 3. Individual data of SMST scores in normal adults}

\begin{tabular}{|c|c|c|}
\hline Number & Age & Score of SMST \\
\hline \multirow[t]{2}{*}{$\mathrm{N}-1(\mathrm{f})$} & $50: 10$ & 구조 24(교합 0점) \\
\hline & & 기능 34 \\
\hline \multirow[t]{2}{*}{$\mathrm{N}-2$} & $57: 1$ & 구조 23(앞니 0점, 교합 1점,) \\
\hline & & 기능 34 \\
\hline \multirow[t]{2}{*}{$N-3$} & $30: 9$ & 구조 24(앞니 1점, 입천장 1점) \\
\hline & & 기능 33(혀좁히기 1점) \\
\hline \multirow[t]{2}{*}{$N-4$} & $39: 0$ & 구조 26 \\
\hline & & 기능 34 \\
\hline \multirow[t]{2}{*}{$N-5$} & $23: 2$ & 구조 26 \\
\hline & & 기능 34 \\
\hline \multirow[t]{2}{*}{$N-6$} & $23: 6$ & 구조 26 \\
\hline & & 기능 30(혀말기 1점, 혀좁히기 1점, 구개반사 0점) \\
\hline \multirow[t]{2}{*}{$N-7(f)$} & $28: 7$ & 구조 24(앞니 1점, 교합 1점) \\
\hline & & 기능 32(구개반사 0점) \\
\hline \multirow[t]{2}{*}{$N-8$} & $24: 1$ & 구조 25(교합 1점) \\
\hline & & 기능 32(구개반사 0점) \\
\hline \multirow[t]{2}{*}{$N-9$} & $20: 3$ & 구조 26 \\
\hline & & 기능 34 \\
\hline \multirow[t]{2}{*}{$N-10$} & $27: 9$ & 구조 23(앞니 1점, 교합 1점, 입천장 1점) \\
\hline & & 기능 31(눈썹 1점, 혀말기 1점, 혀좁히기 1점) \\
\hline \multirow[t]{2}{*}{$N-11$} & $33: 9$ & 구조 22(앞니 1점, 교합 0점, 목젖 1점) \\
\hline & & 기능 32(구개반사 0점) \\
\hline \multirow[t]{2}{*}{$\mathrm{N}-12$} & $37: 11$ & 구조 26 \\
\hline & & 기능 34 \\
\hline \multirow[t]{2}{*}{$N-13$} & $43: 2$ & 구조 25(교합 1점) \\
\hline & & 기능 32(혀말기 1점, 혀좁히기 1점) \\
\hline \multirow[t]{2}{*}{$\mathrm{N}-14$} & $31: 6$ & 구조 22(앞니 0점, 교합 0점) \\
\hline & & 기능 28(눈썹 1점, 입술당기기 1점, 구개따라혀당기기 1점, 혀밀기 1점, 혀말기 1점, 혀좁히기1점) \\
\hline \multirow[t]{2}{*}{$\mathrm{N}-15$} & $22: 7$ & 구조 23(앞니 1점, 교합 0점) \\
\hline & & 기능 34 \\
\hline \multirow[t]{2}{*}{$N-16(f)$} & $39: 6$ & 구조 23(앞니 1점, 교합 1점, 입천장 1점) \\
\hline & & 기능 34 \\
\hline \multirow[t]{2}{*}{$\mathrm{N}-17$} & $24: 0$ & 구조 24(앞니 1점, 목젖 1점) \\
\hline & & 기능 34 \\
\hline
\end{tabular}

